\title{
The influence of changes in glacier extent and surface elevation on modeled mass balance
}

\author{
F. Paul \\ Department of Geography, University of Zurich, Winterthurerstr. 190, 8057 Zurich, Switzerland \\ Received: 27 April 2010 - Published in The Cryosphere Discuss.: 16 June 2010 \\ Revised: 2 November 2010 - Accepted: 25 November 2010 - Published: 10 December 2010
}

\begin{abstract}
Glaciers are widely recognized as unique demonstration objects for climate change impacts, mostly due to the strong change of glacier length in response to small climatic changes. However, glacier mass balance as the direct response to the annual atmospheric conditions can be better interpreted in meteorological terms. When the climatic signal is deduced from long-term mass balance data, changes in glacier geometry (i.e. surface extent and elevation) must be considered as such adjustments form an essential part of the glacier reaction to new climatic conditions. In this study, a set of modelling experiments is performed to assess the influence of changes in glacier geometry on mass balance for constant climatic conditions. The calculations are based on a simplified distributed energy/mass balance model in combination with information on glacier extent and surface elevation for the years 1850 and 1973/1985 for about 60 glaciers in the Swiss Alps. The results reveal that over this period about $50-70 \%$ of the glacier reaction to climate change (here a one degree increase in temperature) is "hidden" in the geometric adjustment, while only $30-50 \%$ can be measured as the long-term mean mass balance. For larger glaciers, the effect of the areal change is partly reduced by a lowered surface elevation, which results in a slightly more negative balance despite a potential increase of topographic shading. In view of several additional reinforcement feedbacks that are observed in periods of strong glacier decline, it seems that the climatic interpretation of long-term mass balance data is rather complex.
\end{abstract}

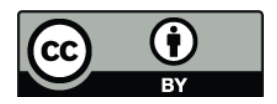

Correspondence to: F. Paul (frank.paul@geo.uzh.ch)

\section{Background}

Glacier changes are widely recognized as the best natural indicators of climatic change (e.g. Lemke et al., 2007) which is also a result of their systematic and globally coordinated monitoring for more than a century (WGMS, 2008). Today, this monitoring follows a tiered strategy within the global terrestrial network for glaciers (GTN-G) as part of the global climate/terrestrial observing systems (GCOS/GTOS) (Haeberli, 2006). The network includes the annual measurement of mass balance at about 60 glaciers and of length changes at about 600 glaciers (e.g. WGMS, 2008). While glacier mass balance can be interpreted as the direct and undelayed reaction to the annual atmospheric conditions, length changes are a delayed, enhanced and filtered signal which reflect atmospheric changes in an integrated way on longer (i.e. climatic) time scales (e.g. Haeberli et al., 2007).

The high correlation of mass balance with atmospheric conditions (mainly temperature and precipitation) permits to derive mass balance from meteorologic parameters (cf. Oerlemans, 2001). For this and other reasons it was (and still is) quite popular to extend the short record of mass balance time series back in time with data from climate stations (e.g. Letréguilly and Reynaud, 1990; Greuell, 1992; Huss et al., 2008; Vincent et al., 2004), upper air conditions from radiosonde measurements (e.g. Rasmussen and Conway, 2001), or other proxies (e.g. Linderholm and Jansson, 2007; Watson and Luckman, 2004). Indeed, such extended mass balance time series might no longer be independent proxies of climatic change and have thus to be treated separately from the measured data (Braithwaite, 2009). However, mean values of mass balance over longer time periods can also be determined independent of climatic data, e.g. from cumulative length changes (e.g. Haeberli and Hoelzle, 1995; Hoelzle et al., 2003).

Published by Copernicus Publications on behalf of the European Geosciences Union. 
For long-term extensions of mass balance time series it is important to consider the changes in glacier geometry (extent and surface elevation). Because nearly all mass balance measurements have been started for hydrological purposes, they refer to the most recent geometry of a glacier. As the geometric changes form an essential part of the dynamic reaction of a glacier to climatic change, the reported mass balance values only reflect a part of the climatic forcing (cf. Harrison et al., 2009) and measured cumulative values increasingly deviate from it. Of course, changes in glacier extent are also a response to changes in surface elevation (glacier thickness) and analysing both independently is only possible with a model. To use time series of mass changes for climate change studies, they have to be independent of climatic data and related to a fixed geometry, the so-called reference surface mass balance (cf. Elsberg et al., 2001; Cox and March, 2004).

While it is possible to directly convert a mean mass change (or ice melt) into the required change of the energy balance (Haeberli and Hoelzle, 1995), there is also an additional climatic interpretation of a long-term mass balance series: in principal, a glacier should reach a new equilibrium state by adjusting its surface properties after a glacier specific response time (e.g. Johannesson et al., 1989). Although this concept is a theoretical one (due to the continuous climate forcing), a more or less stationary front of a "normal" glacier (i.e. without extensive debris cover or a calving terminus) can be interpreted as an indicator of a glacier extent that is in balance with the prevailing climatic conditions. Of course, both need to last for a decade or so to distinguish it from the turning point of short-term oscillations. In the European Alps, the periods 1850-1860, 19201930 and 1970-1980 have seen such equilibrium extents for small to medium-sized glaciers (WGMS, 2008). However, for the largest glaciers with response times longer than a few decades, this is likely only the case for the Little Ice Age (LIA) extents.

Starting from an equilibrium state and assuming a step change in one of the climatic parameters as for example a sudden temperature increase, glaciers should shrink and the mass balance related to the actual glacier surface should become less negative and progressively reach zero again (after full dynamic response). For an ongoing climatic forcing (e.g. a linearly increasing instead of a step change) annual values will remain negative and for an accelerated forcing mass balance becomes increasingly more negative, maybe until a glacier disappears (Pelto, 2010; Harrison et al., 2009). The latter trend (increasingly negative mass balances over shrinking glacier areas) is currently observed in the Alps (Haeberli et al., 2007) but also in many other regions of the Northern Hemisphere (WGMS, 2008). In the Alps, it is likely a response to a one degree temperature increase (step change) around 1985 (Beniston, 2005).

In part, the increasingly negative trend might already be reinforced by positive feedbacks which increase the energy available for melt. The latter can include a gradually de- creased albedo of bare ice due to pollution (Oerlemans et al., 2009; Paul et al., 2005), enhanced down-wasting due to surface lowering (Raymond et al., 2005; Paul and Haeberli, 2008) and disintegration of glaciers (Carturan and Seppi, 2007; Paul et al., 2004). Indeed, for many glaciers in the Alps down-wasting rather than retreat is the dominant reaction to the strongly increased temperatures after 1985 (Paul et al., 2007a; Paul and Haeberli, 2008). When a glacier front does not retreat to higher elevations (i.e. with lower temperatures), but large parts of the surface melt down and decrease in elevation, glacier melt is enhanced by a reinforcement feedback (Raymond et al., 2005; Fischer, 2010). In particular large glaciers with flat tongues at low elevations suffer from this feedback (e.g. Larsen et al., 2007; Schiefer et al., 2007; Paul and Haeberli, 2008). Thus, mass balance values reported from the Alps in the past decade do already include more than the response to climatic change and their interpretation is less clear than in previous periods (cf. also Fischer, 2010). Additionally, changes in glacier extent make the direct climatic interpretation of measured or reconstructed mass balance difficult (Harrison et al., 2009).

The aim of this study is to assess the influence of a changing glacier extent and surface elevation on modeled mass balance for a larger sample of different glaciers using data from two points in time. The experiments should reveal which part of the climate forcing is "visible" in the measured mass balance and which part is "hidden" in the geometric change. In order to investigate the maximum possible effect, reconstructed glacier extents from the LIA and from the 1970s (outlines from the Swiss glacier inventory) were used. Both periods were characterized by near equilibrium conditions for glacier extent. This is important for the calculation of mass balance sensitivities, as these should be calculated with respect to a zero balance to reduce the influence of glacier hypsography. For glaciers with a geometry close to an equilibrium state, the balanced budget assumption is more realistic. Glacier surface elevation is taken from a reconstructed digital elevation model (DEM) for the LIA extent (1850) and a DEM from swisstopo representing the mid-1980s, both having a $25 \mathrm{~m}$ cell spacing. The mass balance is calculated with a distributed energy balance model of intermediate complexity (Machguth et al., 2006b; Paul et al., 2009) that allows calculations over larger regions with several glaciers and sparse input data (here restricted to the daily variability of potential global radiation, temperature, and precipitation).

\section{Study region and input data}

\subsection{Study region}

The selection of the study site is driven by the availability of the required input data and its representativeness for the anticipated effects. The selected region is centred around 


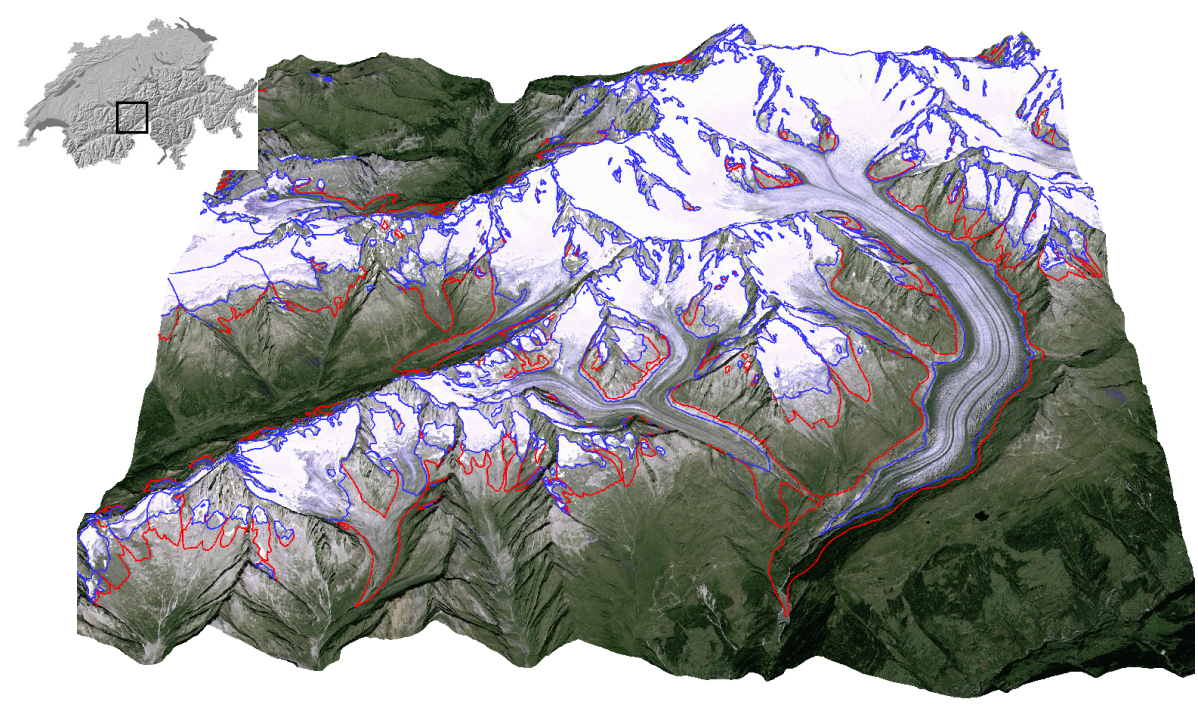

Fig. 1. The study region around Great Aletschglacier in a synthetic oblique perspective view created from a pan-sharpened satellite image (Landsat TM with IRS-1C) and glacier outlines from 1850 (red) and 1973 (blue) draped over a DEM. The region covered is $40 \mathrm{~km}$ by $41 \mathrm{~km}$ in size. The inset map shows the location of the test site in Switzerland (black square). The DEM is reproduced by permission of swisstopo (BA100472).

Great Aletschglacier (Fig. 1), which is the largest glacier in the Alps (area: $86 \mathrm{~km}^{2}$, length $23 \mathrm{~km}$ ). The region contains glaciers of all sizes, types and expositions, rugged highmountain topography, and a steep precipitation gradient from the wet north to the drier south. For this region digitized glacier outlines and $100 \mathrm{~m}$ equidistance elevation contour lines from ca. 1850 are available from Wipf (1999). Compared to other parts of the world, the Swiss topographic maps from the LIA around 1850 are of a high (maybe unique) quality and have already been used for reconstruction of surface topography and geometric extent (Maisch et al., 2000). Moreover, digitized glacier outlines from the 1973 Swiss glacier inventory (Paul, 2007) and the DEM25 level 1 from swisstopo ( $25 \mathrm{~m}$ cell spacing) which was compiled in the mid-1980s are used. It is assumed that this is representative also for the mid-1970s topography, as little change in glacier extent occurred between the mid 1970s and 1980s (Paul et al., 2004) and reported mass balance values indicate nearly balanced budgets during that period (WGMS, 2007).

\subsection{DEM reconstruction}

The DEM from 1850 was reconstructed by combining $100 \mathrm{~m}$ contour lines with the glacier outlines from 1850 and the DEM25 within a Geographic Information System (GIS). The first step is a conversion of the DEM25 to contour lines with $25 \mathrm{~m}$ equidistance and their replacement inside the 1850 glacier outlines with the $100 \mathrm{~m}$ contour lines from 1850 . In a second step, these contours were interpolated within the GIS to a $50 \mathrm{~m}$ cell size DEM using the topogrid routine in Arc/Info (ESRI, 2004). Finally, the $50 \mathrm{~m}$ DEM was bilinearly interpolated to 25 for smoothing and the final eleva- tions inside the 1850 glacier outlines were replaced in the recent DEM25 with the interpolated ones. A shaded relief of the 1850 DEM clearly displays artefacts in flat regions of some glacier tongues close to the original contour lines, but often the elevation difference $(5-30 \mathrm{~m})$ is much smaller than the elevation change from the LIA to the mid 1970s (50$300 \mathrm{~m}$ ). Towards the accumulation area however, the elevation changes decrease and the artefacts create more and more erroneous results (e.g. the 1985 surface can be higher than in 1850). In these regions, the interpolated $1850 \mathrm{DEM}$ was reset to the DEM25. The size of the replaced regions varies from glacier to glacier (between 30 and 70\%). Glaciers smaller than $0.5 \mathrm{~km}^{2}$ in 1850 were excluded from the analysis.

\subsection{Climatic data}

The applied distributed mass balance model requires only limited inputs, but includes the most relevant processes governing mass balance variability in high-mountain topography (Oerlemans, 2001; Paul et al., 2008): temperature $(T)$, precipitation $(P)$ and potential global radiation $(R)$. The mean daily temperature values are generated by a cosine function from an annual mean and range following Oerlemans (1992). The mean annual values for $1850\left(15^{\circ} \mathrm{C}\right)$ were selected to give a mass balance that is close to zero in the mean for the entire region. A $1{ }^{\circ} \mathrm{C}$ higher temperature is used for the simulations with the 1970s glacier extent (Böhm et al., 2001).

The precipitation distribution (annual sums) is taken from the $2 \mathrm{~km}$ gridded climatology by Schwarb et al. (2001), which refers to the period 1971-1990 (Frei and Schär, 1998). This data set is also used for the 1850 model run, as there is no evidence for a trend in precipitation totals since that time 

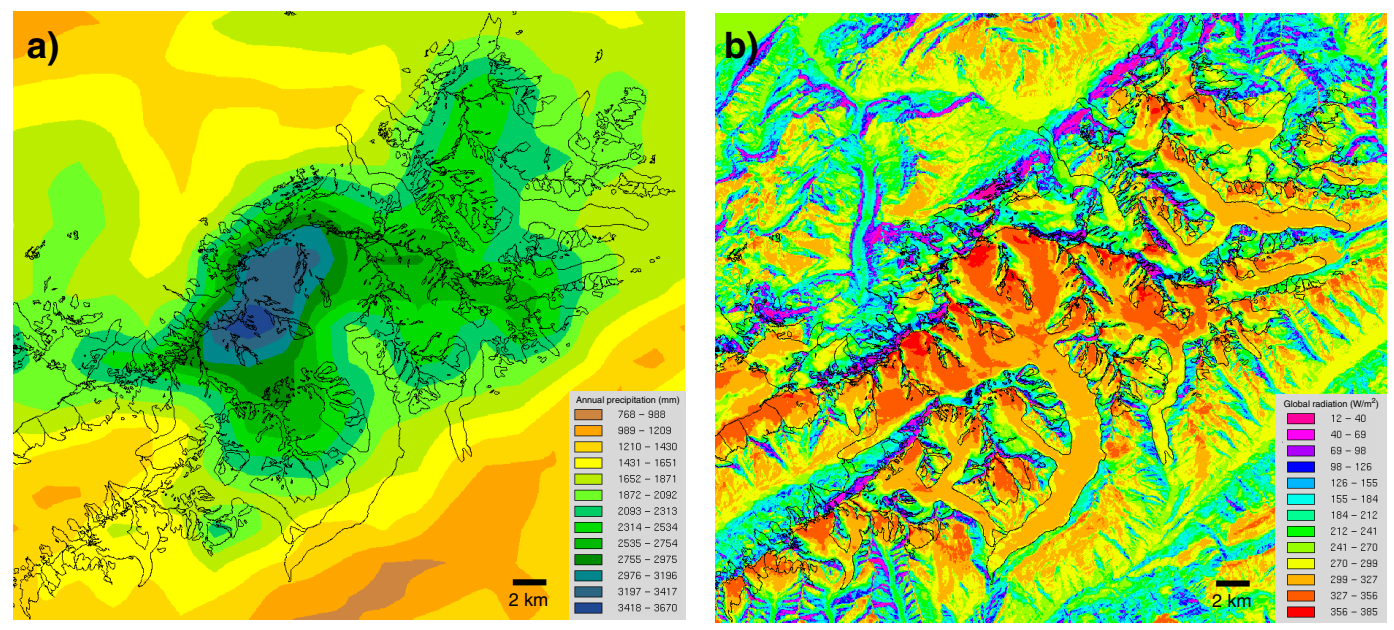

Fig. 2. (a) Mean annual precipitation from the Schwarb et al. (2001) climatology resampled from $2 \mathrm{~km}$ to $25 \mathrm{~m}$ cells with glacier outlines from 1850. (b) Mean daily potential global radiation as modeled by SRAD for day 212 of a year (31 July) using the reconstructed DEM from 1850 .

(Begert et al., 2005) and local precipitation gradients should not have changed too much. Moreover, precipitation is used in some experiments as an additional, locally adapted tuning factor for each glacier, which allows to be less accurate with the absolute values. To get a smoothed input data set, the $2 \mathrm{~km}$ precipitation grid was bilinearly resampled to the $25 \mathrm{~m}$ cells of the model domain (Fig. 2a).

Global radiation has a high temporal and spatial variability. For this study the temporal variability due to cloud cover is neglected by assuming a constant cloud factor of 0.5 for each day of the year and the entire model domain (Meerkötter et al., 2004). However, the spatial variability of the potential (i.e. cloud-free) global radiation is fully accounted for by calculating a mean daily value for each day of the year and the two DEMs from the computer code SRAD (Wilson and Gallant, 2000). All topographic factors (e.g. slope, aspect, sky view factor) are included and changes in global radiation receipt due to a changed glacier geometry are explicitly considered. In Fig. $2 b$ the spatial distribution for the 1850 DEM and day 212 (31 July) is shown as an example.

\section{The mass balance model}

The general approach of the applied surface energy and mass balance model is to include the most important variables for Alpine glaciers $(T, P, R)$ with high precision, while others are parameterized more roughly (cf. Oerlemans, 2001). Such simplified calculations provided rather good results compared to measurements or more complex modeling approaches (Machguth et al., 2006b, 2009; Hock et al., 2007). Details of the model used here were described by Paul et al. (2008) and a validation of model performance can be found in Machguth et al. (2006b) and Paul et al. (2009). The focus is thus here on a short description of some of its basic characteristics. The model physics (e.g. the parameterization of longwave incoming and outgoing radiation) is based on the models developed by Oerlemans $(1991,1992)$ and Klok and Oerlemans (2002) with some modifications to include a forcing by meteorological data in raster format. The model starts at day 274 (on October first of a year) with zero snow depth at all cells of the respective DEM and calculates cumulative mass balance for each cell at daily steps for a full hydrologic year (until 30 September).

Mean daily temperature is derived from a synthetic cosine curve (minimum 30 January) with an annual mean value (see Table 1) and a temperature range of $7.5^{\circ} \mathrm{C}$. The extrapolation to the elevation of each DEM cell uses a constant lapse rate of $6.25^{\circ} \mathrm{C} \mathrm{km}^{-1}$ as applied in previous studies. Precipitation in the model occurs on each fifth day with 1/73 of the annual sum according to the interpolated climatology by Schwarb et al. (2001). Though artificial, this frequency is rather similar to the natural frequency of larger precipitation events. The mean daily potential global radiation is considered using the pre-calculated SRAD grids for each day of the year.

The calculation of turbulent fluxes depends on temperature and humidity but not on wind speed. However, the exchange coefficient for the turbulent fluxes is allowed to increase down-glacier to mimic an increased surface roughness (Oerlemans, 1992). For this purpose a mean equilibrium line altitude (ELA) of $2900 \mathrm{~m}$ is used for the entire model domain. Some other meteorological parameters that are required in the model (e.g. air pressure, humidity) use fixed climatologic mean values that are extrapolated to the DEM with their specific gradients (Machguth et al., 2006b; Paul et al., 2008). A snow albedo of 0.7 is used for freshly fallen snow (with an exponential ageing curve) and ice albedo is set to 0.3 . Snow thickness (in $m$ w.e.) and the spatio-temporal 
Table 1. Overview of the performed model runs. DEM: used digital elevation model, Temp.: used temperature, Mean mb: mean (area weighted) mass balance for the entire region, Mass balance range: range of individual values, Figures: the results are presented in the indicated figures with the number in brackets refering to the scatter plots.

\begin{tabular}{lrrrrll}
\hline Run & DEM & Temp. & $\begin{array}{r}\text { Mean } \\
\text { mb }\end{array}$ & $\begin{array}{r}\text { Mass balance } \\
\text { range }\end{array}$ & Comment & Figure \\
\hline A1 & 1850 & 15 & 0 & $-1.3-1.7$ & initial run 1850 & $3 \mathrm{~b}(7 \mathrm{a})$ \\
A2 & 1850 & 15 & 0 & \pm 0.1 & tuned to zero mass balance & - \\
A3 & 1850 & 16 & 0.64 & $0.35-0.87$ & temperature sensitivity 1850 & 6 (7a, b) \\
\hline B1 & 1985 & 16 & 0 & $-2-1.5$ & initial run 1973 & - \\
B1T & 1985 & 15 & +0.42 & $-1.3-1.8$ & for experiment E1 and E3a/b & - \\
B2 & 1985 & 16 & 0 & \pm 0.1 & tuned to zero mass balance & - \\
B3 & 1985 & 17 & 0.58 & $0.26-0.84$ & temperature sensitivity 1973 & $(7 \mathrm{~b})$ \\
\hline
\end{tabular}

change of the snow line during the year is explicitly modeled. For a thin snow pack the albedo is reduced according to Klok and Oerlemans (2002) and the ice albedo is used when snow thickness is zero. Net balances are derived in the GIS for each glacier from zone statistics using the respective glacier extents (1850 or 1973) as a zone and the obtained mass balance distribution (from the 1850/1985 DEM) as the values.

\section{Experiments}

To obtain comparable results, a rather synthetical set-up is used for the experiments. Three modeling steps can be distinguished: (1) application of the mass balance model using different mean temperatures and the DEMs from 1850 and 1985 as an input (cf. Table 1), (2) zonal averaging with the 1850 and 1973 extents for calculation of a mean mass balance per glacier (cf. Table 2), and (3) calculation of differences to a reference data set (cf. Table 3). For step (1), model run $\mathrm{A} 1$ serves as a reference for the 1850 glacier geometry and B1 for the 1973/1985 conditions. For both runs also a tuning run is performed (A2, B2) that has adjusted precipitation amounts to obtain a zero mass balance for each glacier as a starting point for the sensitivity runs (A3, B3). They use one degree higher mean annual air temperatures but the same tuned precipitation grid as in A2 and B2 (Table 1). One additional run (B1T) was performed that is based on B1 but uses a one degree lower temperature.

For the tuning, the precipitation sensitivity (change in mean mass balance due to a $10 \%$ lower precipitation) was calculated for each glacier and modeled mass balances were divided by this sensitivity to derive the related correction factors. The precipitation grid (Fig. 2b) was corrected with these glacier specific factors (ranging from $-74 \%$ to $+65 \%$ ) and new mass balances were calculated. After the second iteration modeled mass balances were close to zero ( $\pm 0.02 \mathrm{~m}$ w.e.). The zero balance tuning is required to eliminate the influence from the initial balance on the calculated
Table 2. Overview of the glacier extents used for spatial averaging of the calculated mass balance from the model runs listed in Table 1 (column "Run").

\begin{tabular}{|c|c|c|c|c|c|}
\hline Code & Temp. & Run & DEM & Extent & Comment \\
\hline $\mathrm{AR}$ & 15 & A1 & 1850 & 1850 & $\begin{array}{l}\text { Reference experiment } \\
\text { with the } 1850 \mathrm{DEM}\end{array}$ \\
\hline AS & $15+1$ & A3 & 1850 & 1850 & $\begin{array}{l}\text { Temperature sensitivity } \\
\text { for } 1850\end{array}$ \\
\hline BR & 16 & B1 & 1985 & 1973 & $\begin{array}{l}\text { Reference experiment } \\
\text { with the } 1985 \mathrm{DEM}\end{array}$ \\
\hline BS & $16+1$ & B3 & 1985 & 1973 & $\begin{array}{l}\text { Temperature sensitivity } \\
\text { for } 1973\end{array}$ \\
\hline E1 & 15 & B1T & 1985 & 1850 & Change of DEM \\
\hline E2 & 15 & $\mathrm{~A} 1$ & 1850 & 1973 & Change of extent \\
\hline E3a & 15 & B1T & 1985 & 1973 & $\begin{array}{l}\text { Change of DEM and } \\
\text { extent ( } 1850 \text { entities) }\end{array}$ \\
\hline E3b & 15 & B1T & 1985 & 1973 & $\begin{array}{l}\text { Change of DEM and } \\
\text { extent (1973 entities) }\end{array}$ \\
\hline
\end{tabular}

sensitivity. For example, a reduced sensitivity could be possible for a glacier that has already a negative balance with its ELA located in the steeper accumulation region. In this case, the size change of the ablation region is only small for a given ELA shift. The precipitation sensitivity was not re-calculated starting from a zero balance.

Based on the model runs from step (1), different combinations of zonal averaging (listed in Table 2) were performed in step (2). The reference runs AR (BR) are based on the initial runs A1 (B1) and use the respective extent from 1850 (1973) for zonal averaging of mass balance values. The sensitivity experiments AS (BS) are based on the sensitivity runs A3 (B3) and also use the respective extent from 1850 (1973) for zonal averaging. To determine the influence of glacier extent and surface elevation change on mass balance, the model runs $\mathrm{A} 1$ and $\mathrm{B} 1 \mathrm{~T}$ were combined with different extents. In Experiment 1 (E1) mean mass balance values are calculated 
Table 3. Overview on the calculated differences. For each difference input 2 is subtracted from input 1.

\begin{tabular}{llll}
\hline Difference & Input 1 & Input 2 & Figure \\
\hline D1 & A1 & E1 & $4 a$ \\
D2 & A1 & E2 & $4 \mathrm{~b}$ \\
D3 & A1 & E3a & 5a \\
D4 & D3 & E3b & 5b \\
D5 & A2 & A3 & 6 \\
D6 & B2 & B3 & - \\
\hline
\end{tabular}

from model run B1T and the 1850 extents, in E2 mean values are calculated from model run A1 and the 1973 extents, and in E3 mean values are calculated from run B1T but with the 1973 extents. Due to glacier split after 1850, the 1973 extents are considered in two different ways: in E3a all parts that belonged to the former 1850 extent are treated as one entity and in E3b all entities in 1973 are considered separately (Table 2).

In the final step (3) the differences of modeled mean mass balances are calculated (Table 3). Difference 1 (D1) provides the change in mass balance due to a change of the DEM (i.e. surface elevation), D2 due to a change of the extent, and D3 due to changes in both the DEM and glacier extent. The difference D4 results from the different assignment of glacier zones in E3b and is calculated as the difference to D3 to enhance the changes. With these differences it is possible to separately assess the change in mass balance due to surface lowering, decreased glacier extent and a combination of both adjustments. The differences D5 and D6 refer to the sensitivity model runs $\mathrm{A} 3$ and $\mathrm{B} 3$.

\section{Results}

For Figs. 3b, 4, 5 and 6, mean values and the steps of half standard deviations used for colour coding refer to areaweighted means. In general, this value is biased towards the largest glacier and the slightly different arithemtic means are also disussed below. Each figure has its own legend and range of values to better illustrate their spatial variability and to avoid cross-comparisons of individual glaciers. The latter could be misleading as the images refers to different entities and values cannot be simply added up. Only glaciers $>0.5 \mathrm{~km}^{2}$ are considered.

\subsection{Reference runs}

In Fig. 3a the mass balance distribution as obtained by the model is shown for the reference run (A1) and the 1850 glacier extent. For better visibility the image is clipped with the glacier cover. The change in mass balance follows elevation closely, because the ice albedo has been fixed to 0.3 and the potential global radiation in the flat ablation regions of the larger glacier tongues has only a limited variability (Fig. 2b). In the accumulation region, the pattern of the precipitation distribution (Fig. 2a) takes over and governs the spatial variability. The modeled ablation at the terminus of $-10 \mathrm{~m}$ w.e. $\mathrm{a}^{-1}$ at Great Aletschglacier (1450 ma.s.l.), and $-12 \mathrm{~m}$ w.e. $\mathrm{a}^{-1}$ at both Grindelwald Glaciers (1200 m a.s.l.) are in agreement with other approaches using midpoint and minimum elevation together with a fixed mass balance gradient (Haeberli and Hoelzle, 1995). The modeled accumulation of $3.5 \mathrm{~m}$ w.e. near Jungfraujoch ( $3550 \mathrm{~m}$ a.s.l.) is rather high, but only found in small regions. They likely result from unconsidered processes in the mass balance model (e.g. wind drift) and too high precipitation values in the input data set for this region.

The mean mass balance for each glacier without any tuning (AR) is depicted in Fig. 3b, using the above mentioned colour coding. Though the area weighted mean mass balance is close to zero (arithmetic mean is $0.14 \pm 0.84 \mathrm{~m}$ w.e.), there is a large spread of values between -1.3 and $1.7 \mathrm{~m}$ w.e. $\mathrm{a}^{-1}$ for individual glaciers. In general, a distinct spatial pattern with more negative values in the west and east of the study region and balanced to positive values in the central part can be seen. In particular very small glaciers and those at the northern Alpine rim have positive mass balances. For the latter this is obviously due to higher precipitation (Fig. 2a) and reduced global radiation (Fig. 2b). The very negative mass balance of Unteraarglacier (UAG in Fig. 3b) is most likely due to its low surface elevation. In reality, the glacier tongue is covered by a thick debris layer which might reduce ablation by a factor of two or more (Huss et al., 2007).

\subsection{Experiment 1: change of the DEM}

In Fig. 4a the results from experiment 1 (E1) are presented. In E1, glacier extent and climate is constant (1850) but the DEM is changed. This reveals the change in mass balance due to the surface lowering alone. Such calculations are possible as the entire domain is covered by glacier ice in the model and mean mass balance does simply result from statistical calculations with the respective glacier zone. In principle, two opposite effects change mass balance in the two DEMs: on the one hand, the decrease in elevation results in higher temperatures which enhances melt and, on the other hand, the glacier surface can be subject to a stronger shading (better radiation protection) which reduces ablation (e.g. Arnold et al., 2006).

In consequence, the net effect is small and differences in both directions occur $\left(-0.15\right.$ to $0.12 \mathrm{~m}$ w.e. $\left.\mathrm{a}^{-1}\right)$ yielding on average (arithmetic mean) a very small negative value of $-0.02 \pm 0.05 \mathrm{~m}$ w.e. that is not significant. However, the area-weighted mean is $-0.05 \pm 0.05 \mathrm{~m}$ w.e. (Fig. 4a) indicating a trend with glacier size. Indeed, on a scatter plot with glacier size versus mass balance difference slightly increasing negative values can be found towards larger glaciers. This implies that both effects occur for smaller glaciers and 

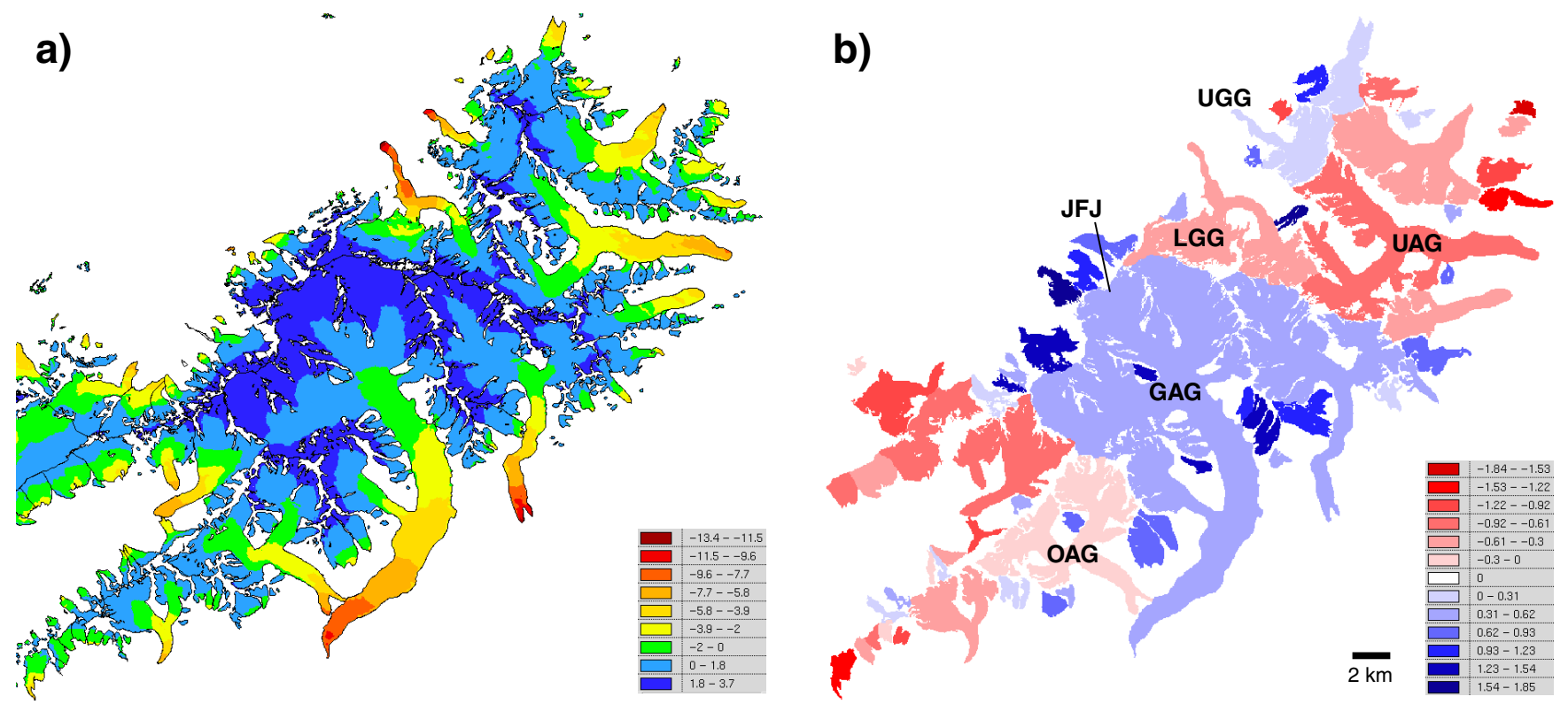

Fig. 3. (a) Mass balance distribution as obtained for the reference run using the DEM and outlines from 1850. (b) Resulting mean mass balance values for each glacier (colour coding in 1/2 standard deviations) for the same model run. Locations mentioned in the text are indicated (JFJ: Jungfraujoch, LGG/UGG: Lower/Upper Grindelwaldglacier, OAG: Oberaletschglacier, GAG: Great Aletschglacier, UAG: Unteraarglacier).
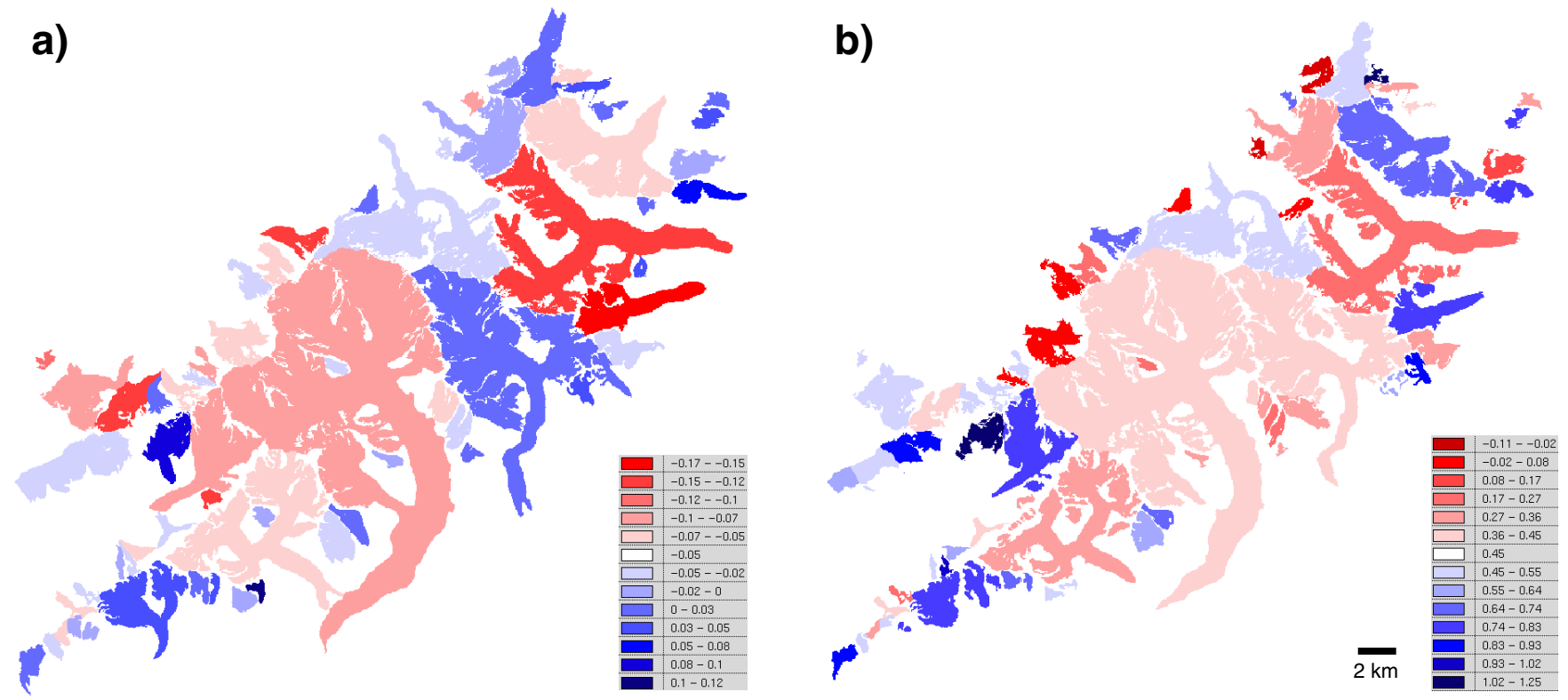

Fig. 4. (a) Change in mean mass balance due to a change of the DEM (difference 1). (b) Change in mean mass balance due to a change of glacier extent (difference 2). 

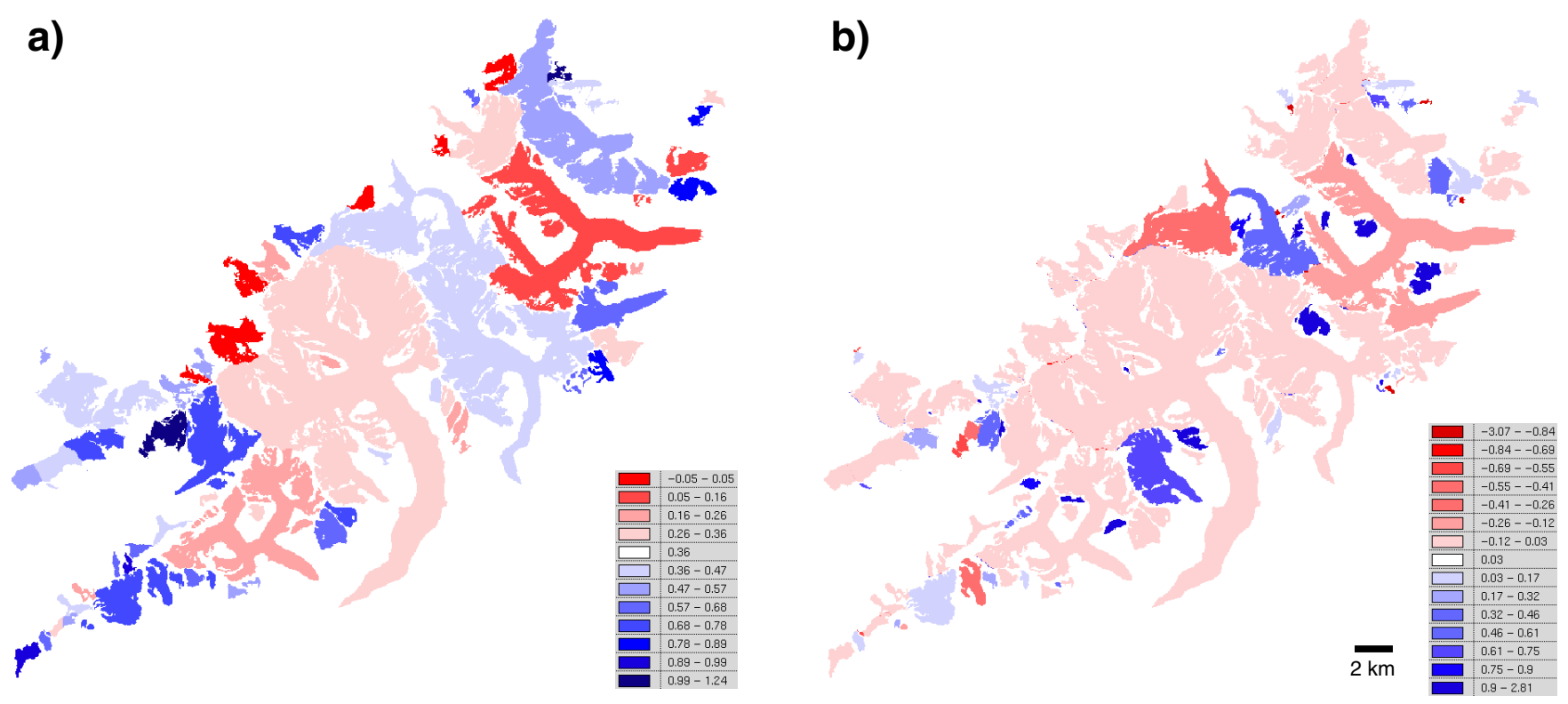

Fig. 5. (a) Change in mean mass balance due to a change of the DEM and glacier extent (difference 3). (b) As Fig. 5a, but here the change in mean mass balance considers glacier split (difference 4).

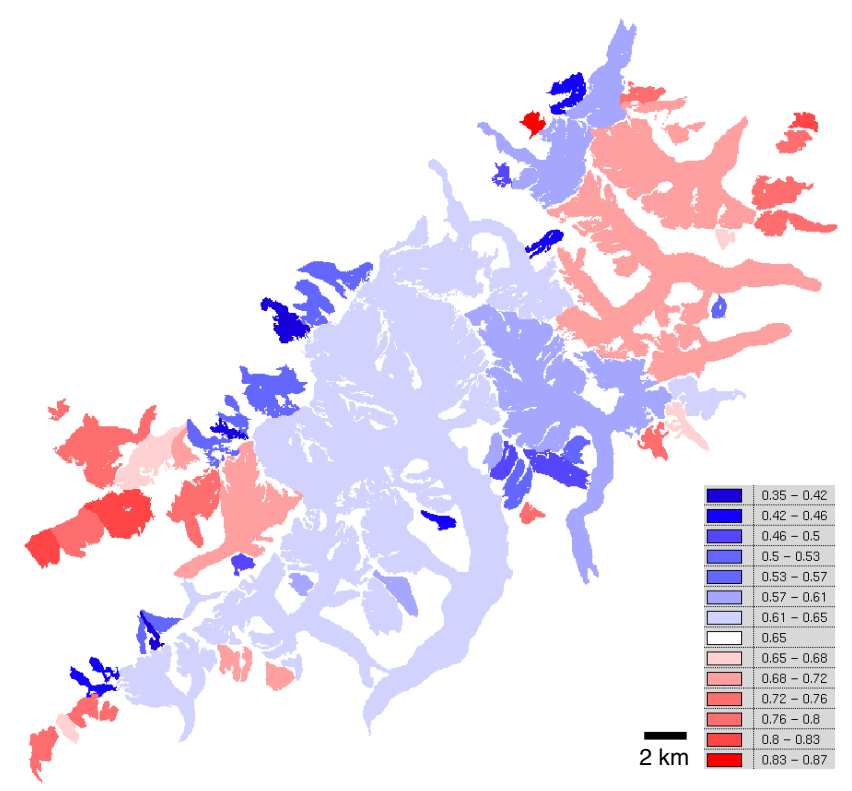

Fig. 6. Mass balance sensitivity for a one degree temperature increase based on the DEM and outlines from 1850 (difference 5).

the increase in temperature due to the lowered surface elevations is more pronounced for larger glaciers. A small negative effect of the surface lowering on the mass balance has also been found in the study by Fischer (2010) for Hintereisferner in Austria.

\subsection{Experiment 2: change of the extent}

In experiment 2 (E2) only the glacier extents are changed and the mass balance from the reference run (A1) with the surface of the 1850 DEM is used for calculation. The resulting differences are depicted in Fig. 4b. The change in areal extent alone results in much more positive mass balances (up to $1.25 \mathrm{~m}$ w.e. $)$ for all glaciers $(0.47 \pm 0.28 \mathrm{~m}$ w.e. in the arithmetic mean) with a markedly different spatial pattern than for E1 (Fig. 4a). In particular, the flat and highly debris covered glacier tongues of Unteraar- and Oberaletschglacier, both with little change in radiation exposure after the areal change, and those glaciers on the northern slopes do not benefit much from the change in extent. Some glaciers even have a slightly more negative mean mass balance after their reduction in size which is basically due to their special topographic conditions, i.e. they lost strongly shaded parts of their tongues.

\subsection{Experiment 3: change of the DEM and the extent}

In experiment 3 (E3a and E3b) both, the DEM and the glacier extent were changed (Fig. 5a). As expected, the mass balance difference is very similar to E2 in the arithmetic mean $(0.46 \pm 0.28 \mathrm{~m}$ w.e. $)$ and more different to $\mathrm{E} 2$ in the area weighted mean $(0.36 \pm 0.29 \mathrm{~m}$ w.e. $)$ as the enhanced melt due to surface elevation decrease is more pronounced for the larger glaciers (E1). When the change is related to the 1973 glacier entities (E3b), several tributaries have a much more positive balance (up to 0.9 mw.e.) compared to E3a, while others have more negative balances as they lost contact with 

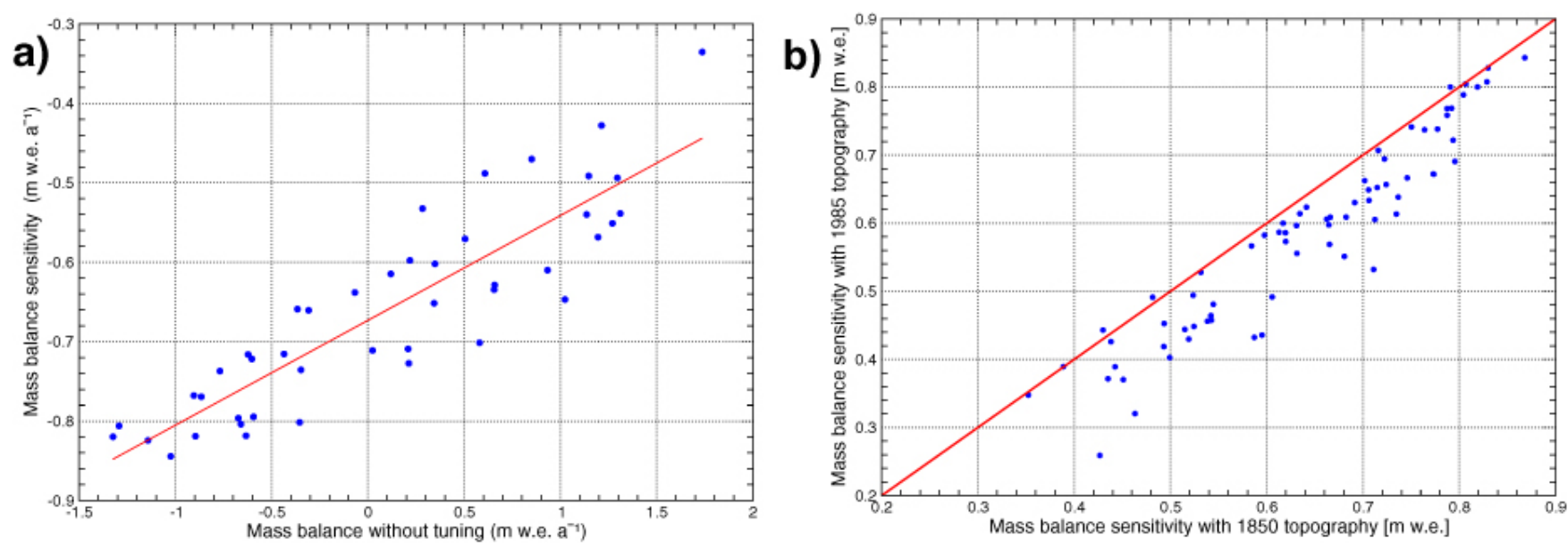

Fig. 7. (a) Comparison of the mean mass balance from the reference run without tuning (AR) with the mass balance sensitivity starting from a tuned zero balance (AS). (b) Scatter plot comparing the mass balance sensitivity for the 1850 DEM and glacier extent with the sensitivity for the 1973 extent and the 1985 DEM (sensitivity runs AS and BS).

higher accumulation areas (Fig. 5b). For large glaciers that only disconnect from a small tributary, only minor changes in mass balance occur.

\subsection{Mass balance sensitivity}

The spatial variability of the mass balance sensitivity from model run A3 (DEM from 1850) and outlines from 1850 (experiment AS in Table 2) is presented in Fig. 6. All glaciers have a negative mass balance sensitivity, mostly between -0.35 and $-0.87 \mathrm{~m}$ w.e. (the arithmetic mean is $-0.63 \pm 0.12 \mathrm{mw}$.e.) for a $1^{\circ} \mathrm{C}$ increase in temperature (as the sensitivity run A3 is subtracted from zero, values are positive in Fig. 6). The values are in good agreement with other studies using different approaches for calculating sensitivity (e.g. Braithwaite and Zhang, 1999; Oerlemans and Fortuin, 1992). The pattern in Fig. 6 shows a surprising similarity to the pattern of the mass balance distribution in the reference run (A1) without tuning (Fig. 3b). Indeed, a linear regression of mass balance and mass balance sensitivity gives a correlation coefficient of $r=0.89$ (Fig. 7a). This implies that the mass balance sensitivity (starting from a zero balance) can also be seen in an untuned reference run of the model. It is assumed that the similarity is a result of the area-elevation distribution (hypsography) of each glacier that might have a strong influence on both values (Furbish and Andrews, 1984).

The mass balance sensitivity was also calculated for the recent DEM (B3) and the 1973 glacier extent (BS in Table 2) to assess how the sensitivity has changed compared to the more recent geometry. Both sensitivities are compared in the scatter plot of Fig. 7b. Apart from eleven glaciers that show virtually no change, the sensitivity for all glaciers decreased by up to $0.15 \mathrm{~m}$ w.e. $\mathrm{a}^{-1}$. To a certain extent this can be explained by the new position of the equilibrium line (EL), which is for the smaller extent higher up and thus closer to steeper terrain. In this terrain, the ca. $150 \mathrm{~m}$ upward shift of the EL (i.e. $1^{\circ} \mathrm{C}$ temperature increase) would result in a comparably smaller change of the size of the ablation area than in flatter regions of a glacier.

\section{Discussion}

\subsection{Interpretation of the results}

Mean measured or indirectly inferred annual mass balance for Alpine glaciers over the period 1850 to the mid $1970 \mathrm{~s}$ was about -0.2 to -0.3 m w.e. $\mathrm{a}^{-1}$ (Haeberli and Hoelzle, 1995; Bauder et al., 2007; Hoelzle et al., 2003; Haeberli et al., 2007; Steiner et al., 2005). Over the same time period, temperatures in the Alps increased by nearly $1^{\circ} \mathrm{C}$ (Böhm et al., 2001). According to the sensitivity studies, such an increase would lead to a mean mass balance change of about $-0.63 \mathrm{~m}$ w.e., which is about 2-3 times higher than measured. According to the experiments presented here, the changes in extent alone result in about $0.47 \mathrm{~m}$ w.e. more positive balances (arithmetic mean), while the surface lowering alone has a negligible effect in the arithmetic mean but accounts for about $0.05 \mathrm{~m}$ w.e. more negative balances in the area weighted mean as the negative effect slightly increases towards larger glaciers. Both changes combined cause about $0.46 \mathrm{~m}$ w.e. more positive balances $(0.36$ in the area weighted mean), which is about the difference between the reconstructed mean mass balance and the theoretical one from the temperature sensitivity. The mean value for both changes (0.36) is slightly different from the sum of the individual values as the changes do not scale linearly.

The split of tributaries can have strong impacts on the mean mass balance of the new parts given that they are 
sufficiently different in size or hypsography. In reality such a separation from tributaries can have severe impacts on the fate of a glacier (e.g. Caresèr glacier, Carturan and Seppi, 2007) or create problems for the correct extrapolation of mass balance measurements (e.g. Hintereisferner, Fischer, 2010). As a general figure, the changes in glacier geometry over the 1850 to $1973 / 1985$ period were responsible for about $1 / 2$ to $2 / 3$ of the response to the temperature increase. The observed near zero mass balances of many Alpine glaciers that occurred during the 1970s can thus be explained with the reconstructed mean mass balance combined with the compensation by geometric changes.

Due to the temperature increase of another degree in the 1980 s, the current extents of most glaciers are again out of balance. The currently observed rapid glacier retreat in the Alps (Citterio et al., 2007; Lambrecht and Kuhn, 2007; Paul et al., 2004, 2007a) will thus continue. Assuming that no further temperature increase will occur, about $40 \%$ of the glacier area of the 1970s would have to disappear for a $150 \mathrm{~m}$ increase in ELA (Paul et al., 2007b; Zemp et al., 2006).

\subsection{Implications for mass balance reconstructions}

The model results have several implications: for proper determination of former mass balances an accurate reconstruction of glacier extent is much more important than that of the surface elevation. This is good news, as the reconstruction of former elevation contours is more error-prone and more uncertain than the determination of former glacier extent. Even where historic topographic maps are available, the elevation contour lines for glacier surfaces are often more hand drawn than measured. Hence, artefacts (like an undulating surface) that can result from the spatial interpolation of a DEM from contour lines with a large equidistance can be neglected.

In principle, somewhat higher surface temperatures at lower elevations and at the same time a slightly stronger shading in these regions could cancel each other out and for some smaller glaciers in this study the increased shading is even the dominant effect. However, the results demonstrate that the lowering of the surface elevation has a negative effect on the mass balance for larger glaciers as also found in a recent study by Fischer (2010). This has also a consequence for the currently observed down-wasting of the larger Alpine glaciers (Paul et al., 2007a; Paul and Haeberli, 2008): when their extent does not change too much (e.g. the glacier terminus rests in a stable position), the down-wasting is selfaccelerating and able to melt down the ice without further climate change. The related processes were recently observed at the disintegrating tongues of Triftglacier and Gauliglacier and have now started at the tongue of Rhoneglacier (see www.swisseduc.ch). In these cases, the formation of lakes in overdeepened glacier beds accelerates glacier melt even further.

Another consequence is related to reconstructing mass balance back in time. When the actual glacier extent and sur- face elevation is considered for mass balance calculation (hydrologic balance), more negative mass balances result for a glacier under the same climatic forcing. The direct comparison of mass balances for glaciers with different extents is thus misleading. For such a comparison the geometric conditions must be the same. Correspondingly, holding glacier extent constant in forward calculations of mass balance (for increasing temperatures) results in more negative balances than actually occur as glacier size is overestimated. On the other hand, reconstructions back in time will be more positive than in reality when glaciers were larger in the past. Such effects are currently only roughly considered in models that calculate past or future glacier changes (e.g. Radic and Hock, 2006). As Nemec et al. (2009) have shown in a transient model run (1865 to 2005) for Morteratsch Glacier, the mass balance for a fixed geometry was about $46 \%$ more negative than the hydrological one, which is in good agreement with the results obtained here.

The general decrease in the mass balance sensitivity for smaller glacier extents has to be considered for long forward integrations in coupled mass balance/flow models. However, this might be limited to the "classical" Alpine glacier type with increasingly steep backwalls towards higher elevations and finally avalanche-fed cirque type glaciers that might not change at all (Hoffmann et al., 2007; DeBeer and Sharp, 2009). In the case of ice caps/ice fields or other glacier types with a different hypsographic curve (more flat towards higher elevations), the sensitivity will likely increase (Furbish and Andrews, 1984). Alpine glaciers that do no longer have an accumulation area will finally also disappear (Maisch et al., 2000; Pelto, 2010).

\subsection{Possible errors of the modelling}

The applied mass balance model as well as the input data include simplifications that have an influence on the modeled mass balance in absolute terms. However, the main results of the study would not change much if a more complex model or a more accurate extrapolation of the glacier surface had been used as the differences in mass balance analysed here are much less influenced by such uncertainties. Moreover, a mass balance model that is based on the energy balance approach is less sensitive to small errors in the input data as some of the errors tend to cancel each other out. For example, regions where artefacts of the reconstructed DEM are present (e.g. a wave pattern) have in most cases two sides, one where mass balance is too negative and one where it is too positive compared to a "correct" surface. In the mean for an entire glacier, both local deviations compensate. However, near the glacier front extrapolation artefacts result in surfaces with a concave instead of a convex curvature and a related underestimation of the solar radiation receipts. This has to be considered when individual glaciers are analysed in detail, for example with mass balance profiles. 
The mass balance model does not consider reduced melting for debris-covered glacier parts or redistribution of snow by wind and avalanches. As is obvious from Fig. 3a, several small glaciers located at high elevations have nearly no ablation area. This indicates that absolute precipitation amounts are too high and/or that snow redistribution can be important (e.g. Machguth et al., 2006a; Paul et al., 2009). In the sensitivity model runs, this is compensated for by adjusting the precipitation until a zero mass balance is obtained for each glacier. Related high correction factors point to glaciers where such processes can be important for the mass balance of the respective glacier (Paul et al., 2008).

\section{Conclusions}

The model runs and zonal averaging experiments presented in this study have shown that from a glacier's response to climate change (as given by its mass balance sensitivity) about $50-70 \%$ is "hidden" in its geometric adjustment and only $30-50 \%$ can be measured or reconstructed (for the LIA to 1973 period). Thereby, the decrease in areal extent results in a mass balance that is on average $0.47 \mathrm{~m}$ w.e. more positive, while the lowering of the surface gives only more negative balances for the larger glaciers but no change (in the mean) for smaller glaciers. For the latter, the effects of an increased shading due to a lowered glacier tongue can also result in a more positive balance. In total and in the mean, the change in mass balance due to the geometric response combined with the measured/reconstructed balances result in adjusted glacier extents for the approximately one degree higher temperatures of the 1970s compared to 1850 .

The strong influence of glacier extent on mean mass balance has several implications: first, both the direct interpretation of mass balance values that refer to a variable geometry and the climatic interpretation of reconstructed/modeled past/future mass balance values is a very complex issue. Second, the same climatic forcing results in more negative mass balances for larger glacier extents and vice versa. Finally, mass balance sensitivities slightly decreased from the LIA to the 1970s glacier extents, for nearly all glaciers in the sample (by $0.06 \mathrm{~m}$ w.e. $\mathrm{a}^{-1}$ on average). This implies that in steep mountain topography shrinking glaciers are becoming less sensitive to climatic change and might thus be able to stabilize their extent. For icefields or icecaps this effect is likely opposite.

Acknowledgements. This study was partly supported by a grant from the EU 5th framework project ALP-IMP (EVK-CT- 200200148) and the Swiss National Science Foundation (21-105214/1). The author thanks J. Fiddes for proof reading the english, A. Wipf for providing the digitized data sets, and W. Haeberli for several helpful comments. Very constructive reviews from R. Giesen, M. Pelto and an anonymous reviewer helped to significantly improve the paper.

Edited by: A. Klein

\section{References}

Arnold, N. S., Rees, W. G., Hodson, A. J., and Kohler, J.: Topographic controls on the surface energy balance of a high Arctic valley glacier, J. Geophys. Res., 111, F02011, doi:10.1029/2005JF000426, 2009.

Bauder, A., Funk, M., and Huss, M.: Ice-volume changes of selected glaciers in the Swiss Alps since the end of the 19th century, Ann. Glaciol., 46, 145-149, 2007.

Begert, M., Schlegel, T., and Kirchhofer, W.: Homogeneous temperature and precipitation series of Switzerland from 1864 to 2000, Int. J. Climatol., 25(1), 65-80, 2005.

Beniston, M.: Mountain climates and climatic change: An overview of processes focusing on the European Alps, Pure Appl. Geophys., 162(8-9), 1587-1606, 2005.

Böhm, R., Auer I., Brunetti, M., Maugeri, M., Nanni, T., and Schöner, W.: Regional temperature variability in the European Alps 1760-1998 from homogenized instrumental time series, Int. J. Climatol., 21, 1779-1801, 2001.

Braithwaite, R. J.: After six decades of monitoring glacier mass balance we still need data but it should be richer data, Ann. Glaciol., 50(50), 191-197, 2009.

Braithwaite, R. J. and Zhang, Y.: Modelling changes in glacier mass balance that may occur as a result of climate changes, Geogr. Ann. A, 81(4), 489-496, 1999.

Carturan, L. and Seppi, R.: Recent mass balance results and morphological evolution of Caresèr Glacier (Central Alps), Geogr. Fis. Din. Quat., 30(1), 33-42, 2007.

Citterio, M., Diolaiuti, G., Smiraglia, C., D’Agata, C., Carnielli, T., Stella, G., and Siletto, G. B.: The fluctuations of Italian glaciers during the last century: a contribution to knowledge about alpine glacier changes, Geogr. Ann. A, 89(3), 167-184, 2007.

Cox, L. H. and March, R. S.: Comparison of geodetic and glaciological mass-balance techniques, Gulkana Glacier, Alaska, USA, J. Glaciol., 50(170), 363-370, 2004.

DeBeer, M. and Sharp, M. J.: Topographic influences on recent changes of very small glaciers in the Monashee Mountains, British Columbia, Canada, J. Glaciol., 55(192), 691-700, 2009.

Elsberg, D. H., Harrison, W. D., Echelmeyer, K. A., and Krimmel, R. M.: Quantifying the effects of climate and surface change on glacier mass balance, J. Glaciol., 47(159), 649-658, 2001.

ESRI: Environmental Systems Research Institute, Arc/Info 9.0, 2004.

Fischer, A.: Glaciers and climate change: Interpretation of 50 years of direct mass balance of Hintereisferner, Global Planet. Change, 71, 13-26, 2010.

Frei, C. and Schär, C.: A precipitation climatology of the Alps from high-resolution rain-gauge observations, Int. J. Climatol., 18(8), 873-900, 1998.

Furbish, D. J. and Andrews, J. T. : The use of hyposometry to indicate long-term stability and response of valley glaciers to changes in mass-transfer, J. Glaciol., 30(105), 199-211, 1984.

Greuell, W.: Hintereisferner, Austria - mass-balance reconstruction and numerical modeling of the historical length variations, J. Glaciol., 38(129), 233-244, 1992.

Haeberli, W.: Integrated perception of glacier changes: a challenge of historical dimensions, in: Glacier Science and Environmental Change, edited by: Knight, P. G., Blackwell, Oxford, 423-430, 2006. 
Haeberli, W. and Hoelzle, M.: Application of inventory data for estimating characteristics of and regional climate-change effects on mountain glaciers: a pilot study with the European Alps, Ann. Glaciol., 21, 206-212, 1995.

Haeberli, W., Hoelzle, M., Paul, F., and Zemp, M.: Integrated monitoring of mountain glaciers as key indicators of global climate change: the European Alps, Ann. Glaciol., 46, 150-160, 2007.

Harrison, W. D., Cox, L. H., Hock, R., March, R. S., and Petit, E. C.: Implications for the dynamic health of a glacier from comparison of conventional and reference-surface balances, Ann. Glaciol., 50(50), 25-30, 2009.

Hock, R., Radic, V., and De Woul, M.: Climate sensitivity of Storglaciaren, Sweden: an intercomparison of mass-balance models using ERA-40 re-analysis and regional climate model data, Ann. Glaciol., 46, 342-348, 2007.

Hoffman, M. J., Fountain, A. G., and Achuff, J. M.: 20th-century variations in area of cirque glaciers and glacierets, Rocky Mountain National Park, Rocky Mountains, Colorado, USA, Ann. Glaciol., 46, 349-354, 2007.

Hoelzle, M., Haeberli, W., Dischl, M., and Peschke, W.: Secular glacier mass balances derived from cumulative glacier length changes, Global Planet. Change, 36, 295-306, 2003.

Huss, M., Sugiyama, S., Bauder, A., and Funk, M.: Retreat scenarios of Unteraargletscher, Switzerland, using a combined ice-flow mass-balance model, Arct. Antarct. Alp. Res., 39(3), 422-431, 2007.

Huss, M., Bauder, A., Funk, M., and Hock, R.: Determination of the seasonal mass balance of four Alpine glaciers since 1865, J. Geophys. Res., 113, F01015, doi:10.1029/2007JF000803, 2008.

Jóhannesson, T., Raymond, C., and Waddington, E.: Time-scale for adjustment of glaciers to changes in mass balance, J. Glaciol., 35(121), 355-369, 1989.

Klok, E. J. and Oerlemans, J.: Model study of the spatial distribution of the energy and mass balance of Morteratschgletscher, Switzerland, J. Glaciol., 48(163), 505-518, 2002.

Lambrecht, A. and Kuhn, M.: Glacier changes in the Austrian Alps during the last three decades, derived from the new Austrian glacier inventory, Ann. Glaciol., 46, 177-184, 2006.

Larsen, C. F., Motyka, R. J., Arendt, A. A., Echelmeyer, K. A., and Geissler, P. E.: Glacier changes in southeast Alaska and northwest British Columbia and contribution to sea level rise, J. Geophys. Res., 112, F01007, doi:10.1029/2006JF000586, 2007.

Lemke, P., Ren, J., Alley, R. B., Allison, I., Carrasco, J., Flato, G., Fujii, Y., Kaser, G., Mote, P., Thomas, R. H., and Zhang, T.: Observations: Changes in Snow, Ice and Frozen Ground, in: Climate Change 2007: The Physical Science Basis. Contribution of Working Group I to the Fourth Assessment Report of the Intergovernmental Panel on Climate Change, edited by: Solomon, S., Qin, D., Manning, M., Chen, Z., Marquis, M., Averyt, K. B., Tignor, M., and Miller, H. L., Cambridge University Press, Cambridge, United Kingdom and New York, NY, USA, 2007.

Letréguilly, A. and Reynaud, L.: Space and Time Distribution of Glacier Mass-Balance in the Northern Hemisphere, Arctic Alpine Res., 22(1), 43-50, 1990.

Linderholm, H. W. and Jansson, P.: Proxy data reconstructions of the Storglaciaren (Sweden) mass-balance record back to AD 1500 on annual to decadal timescales, Ann. Glaciol., 46, 261267, 2007.

Machguth, H., Eisen, O., Paul, F., and Hoelzle, M.: Strong spa- tial variability of accumulation observed with helicopter-borne GPR on two adjacent Alpine Glaciers, Geophys. Res. Lett, 33, L13503, doi:10.1029/2006GL026576, 2006a.

Machguth, H., Paul, F., Hoelzle, H., and Haeberli, W.: Distributed glacier mass balance modelling as an important component of modern multi-level glacier monitoring, Ann. Glaciol., 43, 335343, 2006b.

Maisch, M., Wipf, A., Denneler, B., Battaglia, J., and Benz, C.: Die Gletscher der Schweizer Alpen, Gletscherhochstand 1850, Aktuelle Vergletscherung, Gletscherschwund-Szenarien, vdf Hochschulverlag, Zurich, 2000.

Meerkötter, R., König, C., Bissolli, P., Gesell, G., and Mannstein, H.: A 14-year European Cloud Climatology from NOAA//AVHRR data in comparison to surface observations, Geophys. Res. Lett., 31, L15103, doi:10.1029/2004GL020098, 2004.

Nemec, J., Huybrechts, P., Rybak, O., and Oerlemans, J.: Reconstruction of the annual balance of Vadret da Morteratsch, Switzerland, since 1865, Ann. Glaciol., 50(50), 126-134, 2009.

Oerlemans, J.: A model for the surface balance of ice masses: Part I: alpine glaciers, Z. Gletscherkd. Glazialgeol., 27/28, 63-83, 1991.

Oerlemans, J.: Climate sensitivity of glaciers in southern Norway: application of an energy-balance model to Nigardsbreen, Hellstugubreen and Alfotbreen, J. Glaciol., 38(129), 223-232, 1992.

Oerlemans, J.: Glaciers and Climate Change, A. A. Balkema Publishers, Lisse, 2001.

Oerlemans, J. and Fortuin, J. P. F.: Sensitivity of glaciers and small ice caps to greenhouse warming, Science, 258, 115-118, 1992.

Oerlemans, J., Giesen, R. H., and van den Broeke, M. R.: Retreating alpine glaciers: increased melt rates due to accumulation of dust (Vadret da Morteratsch, Switzerland), J. Glaciol., 55(192), 729_ 736, 2009.

Paul, F.: The New Swiss Glacier Inventory 2000 - Application of Remote Sensing and GIS, Schriftenreihe Physische Geographie, Universität Zürich, 52, 210 pp., 2007.

Paul, F. and Haeberli, W.: Spatial variability of glacier elevation changes in the Swiss Alps obtained from two digital elevation models, Geophys. Res. Lett., 35, L21502, doi:10.1029/2008GL034718, 2008.

Paul, F., Kääb, A., Maisch, M., Kellenberger, T. W., and Haeberli, W.: Rapid disintegration of Alpine glaciers observed with satellite data, Geophys. Res. Lett., 31, L21402, doi:10.1029/2004GL020816, 2004.

Paul, F., Machguth, H., and Kääb, A.: On the impact of glacier albedo under conditions of extreme glacier melt: the summer of 2003 in the Alps, EARSeL eProceedings, 4(2), 139-149, 2005.

Paul, F., Kääb, A., and Haeberli, W.: Recent glacier changes in the Alps observed from satellite: Consequences for future monitoring strategies, Global Planet. Change, 56, 111-122, 2007a.

Paul, F., Maisch, M., Rothenbühler, C., Hoelzle, M., and Haeberli, W.: Calculation and visualisation of future glacier extent in the Swiss Alps by means of hypsographic modelling, Global Planet. Change, 55, 343-357, 2007b.

Paul, F., Machguth, H., Hoelzle, M., Salzmann, N., and Haeberli, W.: Alpine-wide distributed glacier mass balance modelling: a tool for assessing future glacier change?, in: Darkening Peaks: Glacier Retreat, Science, and Society, edited by: Orlove, B., Wiegandt, E., and Luckman, B., University of California Press, 
Berkeley and Los Angeles, 111-125, 2008.

Paul, F., Escher-Vetter, H., and Machguth, H.: Comparison of mass balances for Vernagtferner obtained from direct measurements and distributed modeling, Ann. Glaciol., 50(50), 169-177, 2009.

Pelto, M. S.: Forecasting temperate alpine glacier survival from accumulation zone observations, The Cryosphere, 4, 67-75, doi:10.5194/tc-4-67-2010, 2010.

Radic, V. and Hock, R.: Modeling future glacier mass balance and volume changes using ERA-40 reanalysis and climate models: A sensitivity study at Storglaciaren, Sweden, J. Geophys. Res., 111(F3), F03003, doi:10.1029/2005JF000440, 2006.

Raymond, C., Neumann, T. A., Rignot, E., Echelmeyer, K., Rivera, A., and Casassa, G.: Retreat of Glaciar Tyndall, Patagonia, over the last half-century, J. Glaciol., 51(173), 239-247, 2005.

Rasmussen, L. A. and Conway, H.: Estimating South Cascade Glacier (Washington, USA) mass balance from a distant radiosonde and comparison with Blue Glacier, J. Glaciol., 47(159), 579-588, 2001.

Schiefer, E., Menounos, B., and Wheate, R. : Recent volume loss of British Columbian glaciers, Canada, Geophys. Res. Lett., 34, L16503, doi:10.1029/2007GL030780, 2007.

Schwarb, M., Daly, C., Frei, C., and Schär, C.: Mean annual precipitation throughout the European Alps, 1971-1990, Hydrological Atlas of Switzerland, Landeshydrologie und Geologie, Berne, Plate 2.6., 2001.

Steiner, D., Walter, A., and Zumbühl, H. J.: The application of a non-linear back-propagation neural network to study the mass balance of Grosse Aletschgletscher, Switzerland, J. Glaciol., 51(173), 313-323, 2005.
Vincent, C., Kappenberger, G., Valla, F., Bauder, A., Funk, M., and Le Meur, E.: Ice ablation as evidence of climate change in the Alps over the 20th century, J. Geophys. Res., 109(D10), D10104, doi:10.1029/2003JD003857, 2004.

Watson, E. and Luckman, B. H.: Tree-ring-based mass-balance estimates for the past 300 years at Peyto Glacier, Alberta, Canada, Quaternary Res., 62(1), 9-18, 2004.

WGMS: Glacier Mass Balance Bulletin No. 9 (2004-2005), edited by: Haeberli, W., Zemp, M., and Hoelzle, M., ICSU (FAGS)/IUGG (IACS)/UNEP/UNESCO/WMO, World Glacier Monitoring Service, Zurich, Switzerland, 100 pp., 2007.

WGMS: Global glacier changes: Facts and figuers, edited by: Zemp, M., Roer, I., Kääb, A., Hoelzle, M., Paul, F., and Haeberli, W., UNEP (Geneva) and WGMS (Zurich), 88 pp., 2008.

Wilson, J. P. and Gallant, J. C.: Terrain Analysis: Principles and Applications, Wiley, New York, 2000.

Wipf, A.: Die Gletscher der Berner, Waadtländer und nördlichen Walliser Alpen, Geographisches Institut der Universität Zürich, Schriftenreihe Physische Geographie, 40, 295 pp., 1999.

Zemp, M., Haeberli, W., Hoelzle, M., and Paul, F.: Alpine glaciers to disappear within decades?, Geophys. Res. Lett., 33, L13504, doi:10.1029/2006GL026319, 2006. 